\title{
Cnidoscolus aconitifolius leaf pellet can manipulate rumen fermentation characteristics and nutrient degradability
}

\author{
Pajaree Totakul ${ }^{1}$, Maharach Matra ${ }^{1}$, Sukruthai Sommai ${ }^{1}$, and Metha Wanapat ${ }^{1, \star}$
}

* Corresponding Author: Metha Wanapat Tel:+66-8-1932-4180, Fax: +66-4-3202-368

E-mail: metha@kku.ac.th

${ }^{1}$ Tropical Feed Resources Research and Development Center (TROFREC), Department of Animal Science, Faculty of Agriculture, Khon Kaen University, Khon Kaen 40002, Thailand

ORCID

Pajaree Totakul

https://orcid.org/0000-0002-3990-6550 Maharach Matra

https://orcid.org/0000-0003-2865-1836 Sukruthai Sommai

https://orcid.org/0000-0001-9524-534X

Metha Wanapat

https://orcid.org/0000-0002-7633-052X

Submitted Dec 12, 2020; Revised Jan 11, 2021; Accepted Jan 30, 2021
Objective: Chaya (Cnidoscolus aconitifolius) leaf has been found to be an important source of protein, vitamins, minerals, as well as phytonutrients. The present study aimed to evaluate the effect of Chaya leaf pellet (CHYP) with various level of crude protein (CP) in the concentrate on rumen fermentation characteristics and nutrient degradability in in vitro gas production technique.

Methods: In an in vitro rumen fermentation study the dietary treatments were arranged according to a $3 \times 5$ factorial arrangement in a completely randomized design, consisting of Factor A: three levels of CP of concentrate mixtures (14\%, 16\%, and 18\% CP, respectively) and Factor B: five levels of CHYP supplementation (at $0 \%, 2 \%, 4 \%, 6 \%$, and $8 \%$ of dry matter substrates).

Results: The gas production kinetics, fraction (a) and fraction (b) were lower $(\mathrm{p}<0.05)$ with an increasing CHYP addition. Additionally, the fraction $(\mathrm{a}+\mathrm{b})$ was found to yield a significant interaction $(\mathrm{p}<0.05)$ while the fraction $(\mathrm{c})$ was not impacted by CHYP addition. However, in vitro DM degradability was enhanced and interactive $(\mathrm{p}<0.05)$, using 16\% CP of concentrate with 6\% and 8\% CHYP, when compared with $18 \% \mathrm{CP}$ in the non-addition. Additionally, the treatment with higher $\mathrm{CP}$ of the concentrate was higher in $\mathrm{NH}_{3}-\mathrm{N}$ concentration $(\mathrm{p}<0.001)$ and by CHYP supplementation group $(\mathrm{p}<0.05)$. Nevertheless, protozoal counts in the rumen were remarkably decreased $(p<0.05)$ with increasing level of CHYP supplementation. Furthermore, rumen $\mathrm{C}_{2}$ concentration was lower $(\mathrm{p}<0.05)$ in the treatments with CHYP supplementation, while $\mathrm{C}_{3}$ was significantly increased and interactive $(\mathrm{p}<0.05)$ between levels of CP and CHYP supplementation especially at $8 \%$ CHYP supplementation.

Conclusion: Based on this study, the results revealed CHYP as a promising feed supplement to enhance rumen fermentation and to mitigate methane production. However, in vivo feeding experiments should be subsequently conducted to elucidate the effect of CHYP supplementation on rumen fermentation, as well as ruminant production efficiency.

Keywords: Chaya Leaf; Fodder Shrub; Protein Source; Rumen Fermentation

\section{INTRODUCTION}

Ruminants play a crucial role as generators of food and income for stakeholders globally. However, these livestock systems typically possess a diet which is deficient in crude protein (CP) and are essentially high in structural carbohydrates. Without suitable supplementation, feeding such diets will result in insufficient forage intake, low feed conversion efficiency, and low animal productivity [1]. Russell and Rychlik [2] emphasized the importance of rumen ecology especially, the vital role of microbiomes on rumen fermentation efficiency and the subsequent livestock production system. Traditionally, shrubs and trees are used as feedstuff to supply livestock with energy, protein, and other nutrients $[3,4]$. Some of the most common trees and shrubs used in the diets have been shown to improve reproductive 
performance [5], body growth [6,7] and milk production [8]. The use of tree leaves in animal feeding has been practiced for a long time [9]. Fodder tree leaves are of particular importance because they contain a high level of $\mathrm{CP}$, therefore, they are typically used for feeding buffaloes, beef cattle, dairy cattle, and goats. However, the potential use of an ingredient is commonly determined not only by its CP content but also by the rumen degradability, palatability, and the associative effects with other feeds in the rations [10]. In fact, Idan et al [11] reported that a higher proportion of CP in the fodder tree leaves is present in the form that is highly digestible to ruminants. Moreover, previous studies reported that feed supplement as a fodder tree mixture could enhance ruminal degradation of nutrients, volatile fatty acids (VFA), and microbial growth in the ruminants [12]. An initial in vitro study demonstrated that supplementation of a low-quality roughage with different kinds of tropical fodder such as Arachis pintoi and Cratylia argentea significantly enhanced rumen microbial activity and increased the extent of ruminal organic matter $(\mathrm{OM})$ and fiber degradation [13]. In an in vivo study, Viennasay and Wanapat [14] currently reported that supplementation of fodder shrub (Flemingia) enhanced the nutrient digestibility, feed intake and microbial protein synthesis. Furthermore, depending on the fodder or browse species and their phytonutrients, fodder leaf supplementation could help reduce internal parasite infections [15] and methanogens [16]. The utilization of fodder and shrub leaves in ruminant feeding has been extensively investigated $[1,17,18]$, nevertheless, some practical aspects remain to be explored.

The fodder tree leaves are highly preferred feedstuffs, since they exhibit high palatability and support the performance of livestock. A type of fodder shrub is commonly known as Chaya (Cnidoscolus aconitifolius). Chaya is an evergreen, insect/disease resistant and a drought-deciduous, shrub up to $6 \mathrm{~m}$ in height with alternate palmate lobed leaves. The leaves are large, $32 \mathrm{~cm} \times 30 \mathrm{~cm}$, and succulent. It originated as a domesticated vegetable in the Maya region of Guatemela, Belize, South-East Mexico during pre-Cambrian period and due to its ease of cultivation and potential productivity, the plant has spread all over the world including the tropics $[19,20]$. Chaya can be grown year-round and it is fast growing. In Thailand, it can grow well in the hot-rainy season (May-September) [20]. Normally, it can produce 4.9 to $7.4 \mathrm{~kg}$ of fresh leaf per month, with annual yield ranging from 4,999 to 8,333 $\mathrm{kg} / \mathrm{ha}$. This plant has been reported to be a good source of protein with a good profile of amino acids [21] and to contain high levels of vitamins, minerals and especially phytonutrients [22]. Additionally, the phytonutrients reduced the population of the rumen protozoa. The reduction of methane producing microorganisms is reflective of the decrease in methane production [23]. Chaya leaf contains high levels of proteins and minerals, as well as having a beneficial effect on rumen fermentation, hence Chaya is a potential source of fodder to be used to improve ruminant production. Chaya appears to be a great supplement with high feed efficiency; however, there is a limited information associated with the use Chaya as a feed pellet supplementation. Therefore, the objective of this study was to investigate the potential use of Chaya as a feed pellet with different protein levels of concentrate mixture on ruminal fermentation characteristics, in vitro degradability, and the fermentation end-products.

\section{MATERIALS AND METHODS}

\section{Animal care and management}

The experiment procedure was approved by the Institute of Animals for Scientific Purpose Development (IAD), Thailand (record no. U1-06565-2526).

\section{Preparation of Chaya leaf pellet}

After regrowth at about 4 months, Chaya leaf and young stem (CLS) were harvested from Khon Kaen province, Thailand. The harvested Chaya biomass was then chopped to 2 to $3 \mathrm{~mm}$ in length and then sun-dried for 2 to 3 days. Dried Chaya was ground to pass 1-mm screen size using Cyclotech Mill (Cyclotech Mill, Tecator, Hoganas, Sweden). Pellets containing $90 \%$ ground CLS, $1 \%$ molasses, $9 \%$ cassava starch, and water (Table 1) and were formulated as a pellet by Ryuzo-kun pelleting machine (Kakiuchi Co., Ltd, Nankoku, Kochi, Japan), then sundried for about 2 to 3 days and stored in the big plastic boxes for feeding.

\section{Experimental design, animals, and dietary substrate treatment}

The $3 \times 5$ factorial arrangement in a completely randomized design (CRD) was imposed. Factor A: three ratios of CP of concentrate mixture (at 14\%, 16\%, and 18\% CP) and Factor B: five levels of Chaya leaf pellet (CHYP) at $0 \%, 2 \%, 4 \%, 6 \%$, and $8 \%$ of dry matter substrates. The CHYP, concentrate mixtures, and rice straw were oven-dried at $60^{\circ} \mathrm{C}$ for 48 hour and were ground through sieve 1 -millimeter before using in the experiment. Ratios of roughage (R) to concentrate (C) (R:C, 70:30) was used in a concentrate mixture. Feed and chemical compositions of concentrate, rice straw and CHYP of the experiment are presented in Table 1.

The samples of concentrates, CHYP, and rice straw were separated into two separate amounts: the first part was used for DM analysis [24] and the second part was dried in the oven $\left(60^{\circ} \mathrm{C}\right)$ for 3 to 4 days, ground to pass a 1-mm screen (Cyclotec 1093 Sample mill, Tecator, Sweden), and were analyzed for OM and CP according to AOAC [24] method. Neutral detergent fiber (NDF) and acid detergent fiber (ADF) on ash-free basis were analyzed by an Ankom fibre analyzer incubator (model no. ANKOM200, ANKOM, Fairport, NY, 
Table 1. Ingredients and chemical composition of concentrates, rice straw and Cnidoscolus aconitifolius leaf pellet used in the experiment

\begin{tabular}{|c|c|c|c|c|c|}
\hline \multirow{2}{*}{ Items } & \multicolumn{3}{|c|}{ Concentrates } & \multirow{2}{*}{ CHYP } & \multirow{2}{*}{ Rice straw } \\
\hline & $\%$ CP 14 & 16 & 18 & & \\
\hline \multicolumn{6}{|l|}{ Ingredients (\% as fed) } \\
\hline Dried brewery's grain & 10 & 13 & 15.5 & - & - \\
\hline Rice bran & 5.5 & 5.5 & 5 & - & - \\
\hline Palm meal & 8 & 8 & 8 & - & - \\
\hline Molasses & 1 & 1 & 1 & 1 & - \\
\hline Sulfur & 1 & 1 & 1 & - & - \\
\hline Mineral mixed ${ }^{1)}$ & 1 & 1 & 1 & - & - \\
\hline Salt & 1 & 1 & 1 & - & - \\
\hline Chaya leaf meal & - & - & - & 90 & - \\
\hline Organic matter & 90.3 & 90.6 & 90.5 & 87.1 & 84.5 \\
\hline Ash & 9.7 & 9.4 & 9.5 & 12.7 & 15.5 \\
\hline Crude protein & 13.9 & 16.3 & 17.7 & 23.4 & 2.9 \\
\hline Neutral detergent fiber & 16.8 & 20.7 & 21.5 & 19.1 & 81.6 \\
\hline Acid detergent fiber & 10.4 & 11.1 & 11.6 & 16.8 & 56.2 \\
\hline Condensed tannins & - & - & - & 2.3 & - \\
\hline Total flavonoids & - & - & - & 7.6 & - \\
\hline Minerals (\%) & - & - & - & - & - \\
\hline Phosphorus (P) & - & - & - & 0.71 & - \\
\hline Potassium (K) & - & - & - & 0.56 & - \\
\hline Calcium (Ca) & - & - & - & 4.70 & - \\
\hline Isoleucine & - & - & - & 17.4 & - \\
\hline Leucine & - & - & - & 10.6 & - \\
\hline Tryptophan & - & - & - & 26.6 & - \\
\hline Lysine & - & - & - & 3.2 & - \\
\hline
\end{tabular}

CHYP, Chaya (Cnidoscolus aconitifolious, Mill. Johnston) leaf pellet; CP, crude protein.

1) Minerals, contains per kg: 4,000,000 IU vitamin A; 400,000 IU Vitamin $D_{3} ; 4,000$ IU vitamin E; 0.002 g vitamin B $12 ; 16$ g Mn; 24 g Fe; 10 g Zn; 2 g Cu; 0.05 g Se; $0.2 \mathrm{~g} \mathrm{Co:} 0.5 \mathrm{~g} \mathrm{I}$.

USA). Condensed tannins (CT) were chemically analysed by the vanillin- $\mathrm{HCl}[25]$ method, as modified by Wanapat and Poungchompu [26]. The total flavonoid concentration was analyzed by using the Folin-Ciocalteu reagent method [27], while minerals were analyzed using an Atomic absorption spectrometer (Model analytic jena nova 350) with the absorbance set at $425 \mathrm{~nm}$ spectrophotometrically (Shimadzu, Kyoto, Japan).

Animal and preparation of rumen inoculum

Four, rumen-fistulated dairy steers with liveweight of $240 \pm 10$ $\mathrm{kg}$ were the donors of rumen fluid. Steers received concentrate $(16 \% \mathrm{CP})$ as a supplement at $0.5 \%$ body weight and rice straw was offered ad libitum for the period of at least 3 weeks. The experimental cattle were individually penned where clean fresh water and mineral blocks lick were available. Approximately 2,400 $\mathrm{mL}$ of the rumen fluid samples was collected before the morning feeding. The fluid was carefully filtered through four layers of cheesecloth and transferred into pre-warmed thermos flask and was then transported to the laboratory for later analyses. 


\section{In vitro fermentation of substrates}

Two hundred milligrams of feed samples were weighed into $60 \mathrm{~mL}$ serum bottles on various times of incubation with triplicates including three replications of blank. The in vitro gas technique procedure [28], was employed in all steps. All fermentation bottles were tightly covered with stoppers and aluminium caps and were incubated in a water bath at $39^{\circ} \mathrm{C}$ for $1 \mathrm{~h}$ before filling with $30 \mathrm{~mL}$ of mixed rumen inoculum [28]. The medium solution preparation and all steps were those described in detail by Blummel and Orskov [29].

\section{Sample collection and analysis}

Gas kinetic production: the gas production was measured at $0,2,4,6,12,24,48,72$, and $96 \mathrm{~h}$ of incubation. Cumulative gas production data were fitted to the model of Ørskov and McDonald [30], as follow:

$$
\mathrm{Y}=\mathrm{a}+\mathrm{b}\left(1^{-\mathrm{e}-\mathrm{ct}}\right)
$$

Where $\mathrm{a}=$ the gas production from the immediately soluble fraction $(\mathrm{mL}), \mathrm{b}=$ the gas production from the insoluble fraction $(\mathrm{mL}), \mathrm{c}=$ the gas production rate constant for the insoluble fraction $(\mathrm{mL} / \mathrm{h}), \mathrm{t}=$ incubation time $(\mathrm{h}), \mathrm{a}+\mathrm{b}=$ the potential extent of gas production $(\mathrm{mL}), \mathrm{Y}=$ gas produced at time " $\mathrm{t}$ " ( $\mathrm{mL})$.

In vitro dry matter digestibility (IVDMD): Preparation and calculation were those reported by Van Soest and Robertson [31], as follows:

\section{IVDMD \\ $=[(\mathrm{DM}$ of feed taken for incubation $-\mathrm{DM}$ of residue $) \times 100]$ /DM of feed taken for incubation}

Determination of fermentation parameters: The rumen inoculum mixtures were sampled at 12 and $24 \mathrm{~h}$ of fermenting post inoculation. The $\mathrm{pH}$ was immediately measured using a portable $\mathrm{pH}$ temperature meter (HANA instruments $\mathrm{HI}$ 8424 microcomputer Singapore). Rumen inoculum fluid was sampled at $12 \mathrm{~h}$ and $24 \mathrm{~h}$ post inoculation. Then filtered through four layers of cheesecloth. Samples were divided into three separate parts. Rumen fluid of $18 \mathrm{~mL}$ were then sampled and placed in a bottle to which $2 \mathrm{~mL}$ of $1 \mathrm{M} \mathrm{H}_{2} \mathrm{SO}_{4}$ were added to stop the fermentation process of microbial activity and then centrifuged at 3,000 $\times \mathrm{g}$ for 10 minutes. In total, 10 $\mathrm{mL}$ of the supernatant portion were taken and analyzed for the VFAs by using high performance liquid chromatography [32] and rumen ammonia nitrogen $\left(\mathrm{NH}_{3}-\mathrm{N}\right)$ by Kjeltech Auto 1030 Analyzer [24].

The second part $1 \mathrm{~mL}$ of rumen fluid was collected and kept in a plastic bottle which $9 \mathrm{~mL}$ of $10 \%$ formalin solution was added for measuring the protozoal population using a total direct count method by haemocytometer [33]. Methane production was calculated according to Moss et al [34] was followed $\mathrm{CH}_{4}$ emission $=0.45$ (acetate) -0.275 (propionate) +0.40 (butyrate).

\section{Statistical analysis}

All data collected from the experiments were analyzed as a $3 \times 5$ factorial arrangement in a CRD using the PROC general linear model of SAS [35]. The statistical parameters were levels of $\mathrm{CP}$, CHYP levels, and levels of $\mathrm{CP} \times \mathrm{CHYP}$ levels interactions. Differences among statistical treatment parameters with $p<0.05$ and $p<0.001$ were taken as significant differences.

\section{RESULTS}

\section{Chemical compositions}

The chemical compositions of CHYP, concentrate, and rice straw are presented in Table 1 . Three concentrates mixtures were formulated to contain different levels of protein (14\%, $16 \%$, and $18 \% \mathrm{CP}$ ). The CHYP contained $90.3 \% \mathrm{DM}, 23.4 \%$ CP, $19.1 \%$ NDF, $216.8 \%$ ADF, $12.7 \%$ ash, and $2.3 \%$ CT. In addition, essential amino acid profile was higher in CHYP which contained good profiles of tryptophan, phenylalanine, threonine, valine, leucine, lysine, and isoleucine. Moreover, CHYP contained $0.56 \% \mathrm{~K}, 4.70 \% \mathrm{Ca}, 1.79 \% \mathrm{Mg}, 0.71 \% \mathrm{P}$, $0.09 \% \mathrm{Na}$, and $7.6 \%$ total flavonoid. Rice straw contained 90.2\% DM, 81.6\% NDF, 56.2\% ADF, and 15.5\% ash.

\section{Gas production kinetics and in vitro dry matter digestibility}

Cumulative gas production and gas production kinetics are given in Table 2. The CP level in the concentrate mixture and CHYP impacted on the immediately soluble fraction (a) and insoluble fraction (b) $(\mathrm{p}<0.001)$. The gas production rate constant values for the insoluble fraction ratio (c) were not found to be interactive ( $p>0.05$ ). While the potential extent of gas production $(\mathrm{a}+\mathrm{b})$ was significantly interactive, as well as the cumulative gas production at $96 \mathrm{~h}$. Furthermore, the CHYP supplementation factor resulted in the highest IVDMD, while the lowest was found in the non-supplementation group.

\section{Rumen fermentation}

As shown in Table 3, the average values of rumen $\mathrm{pH}$ at 12 and $24 \mathrm{~h}$ were not changed by either the concentrate and/or by the CHYP (6.8 to 7.0). There was no interaction between $\mathrm{NH}_{3}-\mathrm{N}$ concentration ( $\left.\mathrm{p}>0.05\right)$ and the $\mathrm{CP}$ of concentrate or CHYP supplementation. Higher levels of $\mathrm{CP}$ of concentrate and CHYP supplementation increased the $\mathrm{NH}_{3}-\mathrm{N}$ concentration $(\mathrm{p}<0.001)$, while the protozoal count was greatly reduced $(\mathrm{p}<0.05)$ by the CHYP supplementation.

Rumen volatile fatty acids concentration and methane 
Table 2. Effects of supplementation of Cnidoscolus aconitifolius leaf pellet with various levels of protein of concentrate on total gas production and in vitro dry matter digestibility

\begin{tabular}{|c|c|c|c|c|c|c|c|}
\hline \multirow{2}{*}{ Concentrates } & \multirow{2}{*}{$\begin{array}{c}\text { CHYP levels }{ }^{1)} \\
\text { (\% of DM substrate) }\end{array}$} & \multicolumn{4}{|c|}{ Gas kinetics $^{2)}$} & \multirow{2}{*}{$\begin{array}{l}\text { Cumulative gas }(\mathrm{mL}) \\
\text { produced at } 96 \mathrm{~h}\end{array}$} & \multirow{2}{*}{$\operatorname{IVDMD}^{3)}(\%)$} \\
\hline & & a & b & c & $a+b$ & & \\
\hline \multirow[t]{4}{*}{$14 \% \mathrm{CP}$} & 0 & -6.3 & 65.0 & 0.078 & 53.5 & 42.4 & 53.1 \\
\hline & 4 & -0.9 & 60.4 & 0.059 & 43.8 & 47.9 & 53.7 \\
\hline & 6 & -2.8 & 59.3 & 0.065 & 46.4 & 49.7 & 56.1 \\
\hline & 8 & -0.9 & 59.2 & 0.055 & 46.9 & 49.5 & 57.8 \\
\hline \multirow{4}{*}{$16 \% \mathrm{CP}$} & 2 & -1.2 & 59.4 & 0.044 & 60.7 & 54.4 & 58.7 \\
\hline & 4 & -0.2 & 62.9 & 0.041 & 63.1 & 56.2 & 59.5 \\
\hline & 6 & -0.1 & 42.0 & 0.046 & 40.7 & 55.6 & 61.5 \\
\hline & 8 & -0.5 & 52.0 & 0.068 & 52.4 & 56.9 & 60.9 \\
\hline \multirow[t]{2}{*}{$18 \% \mathrm{CP}$} & 0 & -7.4 & 65.0 & 0.063 & 57.6 & 55.7 & 59.0 \\
\hline & 2 & -6.0 & 64.3 & 0.068 & 58.3 & 57.4 & 59.7 \\
\hline SEM & & 1.09 & 3.48 & 0.013 & 3.22 & 3.08 & 1.44 \\
\hline $\mathrm{CP}$ & & $\star \star$ & $\star \star$ & * & $\star \star$ & $\star \star$ & * \\
\hline CHYP & & $\star \star$ & $\star \star$ & ns & $\star$ & $\star$ & $\star \star$ \\
\hline Interaction & & ns & ns & ns & $\star$ & * & ns \\
\hline
\end{tabular}

CHYP, Cnidoscolus aconitifolius leaf pellet; IVDMD, in vitro dry matter digestibility; CP, crude protein; SEM, standard error of mean.

1) $0 \%, 2 \%, 4 \%, 6 \%$, and $8 \%$ of total substrate.

${ }^{2)} \mathrm{a}$, the gas production from the immediately soluble fraction; $\mathrm{b}$, the gas production from the insoluble fraction; $\mathrm{c}$, the gas production rate constant for the insoluble fraction ratio; $a+b$, the gas potential extant of gas production.

3) Average for 12 and $24 \mathrm{~h}$.

ns, not significant; ${ }^{*} p<0.05, * \star p<0.001$

\section{production}

The total VFA profile was influenced by high of $\mathrm{CP}$ of concentrate $(\mathrm{p}<0.001)$ and CHYP supplementation $(\mathrm{p}<0.05)$. Acetate $\left(\mathrm{C}_{2}\right)$ production was found lower $(\mathrm{p}<0.05)$ in the treatments with CHYP supplementation. Additionally, propionate $\left(\mathrm{C}_{3}\right)$ was significantly interactive $(\mathrm{p}<0.05)$ between the levels of CP of concentrate and CHYP levels, especially at $16 \% \mathrm{CP}$ and at $6 \%$ or $8 \%$ CHYP supplementation. Furthermore, the interaction between level of $\mathrm{CP}$ of concentrate and the CHYP levels reduced the butyrate $\left(\mathrm{C}_{4}\right), \mathrm{C}_{2}: \mathrm{C}_{3}$ ratio and methane production $\left(\mathrm{CH}_{4}\right)$ particularly, at $16 \% \mathrm{CP}$ and with $6 \%$ and $8 \%$ CHYP inclusion (Table 4 ).

\section{DISCUSSION}

\section{Chemical composition}

Fodder tree or shrub, in particular Chaya has been reported to contain high level of CP ranging from $26 \%$ to $29 \%$ on DM basis [19,36-39]. The CP of CHYP under this experiment was $23.4 \%$ and relatively lower than previous reports. Importantly, CHYP contained 2.3\% CTs and 7.6\% flavonoids. Under this study, these values could be due to a number of factors namely, stage of growth, soil quality, rainfall and variety etc. Furthermore, the Chaya contained a good profile of amino acids both essential and non-essential especially methionine, lysine, tryptophan and phenylalanine etc. Nevertheless, the amino acid profile of CHYP used under this experiment was similar to those reported by other researchers $[37,38,40]$.

\section{Gas production kinetics and in vitro dry matter digestibility}

Based on this study, the gas kinetics, and immediately soluble fraction (a) were significantly different by the level of $\mathrm{CP}$ of concentrate. This enhanced value of gas kinetics (a) could be attributed to the higher soluble fraction. This may be due to CHYP having higher nutrients such as $\mathrm{CP}$ and vitamins, resulting in effective rumen fermentation. Under this study, the insoluble feed substrate (b), the gas production potential extent $(\mathrm{a}+\mathrm{b})$ was lower $(\mathrm{p}<0.001)$ in concentrate with $14 \%$, $16 \%$, and $18 \% \mathrm{CP}$, when the supplementation of CHYP level increased $(\mathrm{p}<0.05)$. As reported by Ørskov and McDonald [30] the increase in gas production $(\mathrm{a}+\mathrm{b})$ led to the decrease of the fraction (c) rate constant. Nevertheless, supplementation of CHYP impacted the cumulative gas production (at $96 \mathrm{~h}$ ). Increasing of gas production in the present work might be due to CHYP supplementation which improved rumen fermentation and nutrient digestibility. Accordingly, Norrapoke et al [41] reported that used higher level of dietary CP 
Table 3. Effects of supplementation of Cnidoscolus aconitifolius leaf pellet with various levels of protein of concentrate on rumen fermentation

\begin{tabular}{|c|c|c|c|c|}
\hline Concentrates & $\begin{array}{c}\text { CHYP }^{1)} \\
\text { (\% of DM } \\
\text { substrate) }\end{array}$ & $\mathrm{pH}$ & $\begin{array}{c}\mathrm{NH}_{3}-\mathrm{N} \\
(\mathrm{mg} / 100)\end{array}$ & $\begin{array}{c}\text { Protozoa } \\
\left(\times 10^{6} \text { cells } / \mathrm{mL}\right)\end{array}$ \\
\hline \multirow[t]{5}{*}{$14 \% \mathrm{CP}$} & 0 & 6.8 & 12.2 & 4.0 \\
\hline & 2 & 6.9 & 14.3 & 4.2 \\
\hline & 4 & 6.8 & 14.0 & 3.7 \\
\hline & 6 & 7.0 & 14.4 & 3.4 \\
\hline & 8 & 7.0 & 15.0 & 3.5 \\
\hline \multirow[t]{5}{*}{$16 \% \mathrm{CP}$} & 0 & 6.8 & 16.7 & 4.1 \\
\hline & 2 & 6.8 & 16.2 & 3.9 \\
\hline & 4 & 6.9 & 17.8 & 3.2 \\
\hline & 6 & 6.8 & 18.1 & 3.3 \\
\hline & 8 & 6.8 & 17.6 & 2.8 \\
\hline \multirow[t]{5}{*}{$18 \% \mathrm{CP}$} & 0 & 6.9 & 18.4 & 3.2 \\
\hline & 2 & 7.0 & 18.8 & 3.4 \\
\hline & 4 & 6.9 & 19.5 & 2.4 \\
\hline & 6 & 6.9 & 20.3 & 2.8 \\
\hline & 8 & 7.0 & 19.4 & 2.6 \\
\hline SEM & & 0.097 & 0.56 & 0.33 \\
\hline $\mathrm{CP}$ & & ns & $\star \star$ & $\star \star$ \\
\hline CHYP & & ns & $\star \star$ & * \\
\hline Interaction & & ns & ns & ns \\
\hline
\end{tabular}

CHYP, Cnidoscolus aconitifolius leaf pellet; DM, dry matter; CP, crude protein; SEM, standard error of mean.

1) $\mathrm{CHYP}$, Chaya leaf pellet at $0 \%, 2 \%, 4 \%, 6 \%$, and $8 \%$ of total substrate. ns, not significant; ${ }^{\star} \mathrm{p}<0.05,{ }^{*} \mathrm{p}<0.001$. resulted in an increase of gas production, in vitro digestibility. While in this study the IVDMD was enhanced by a high level of CP of the concentrate and by CHYP supplementation. Similarly, Anantasook and Wanapat [42] revealed that the gas production and IVDMD were linearly increased with increasing level of CP. Our results could be due to the greater IVDMD with higher level of CP and the supplementation of CHYP. This higher of CP content enhanced the nutrient digestibilities in the rumen [43]. Moreover, Woodward et al [44] stated that plants containing less than 5\% CT did not impact on nutrient degradability. In this trial, the CTs in CHYP were $2.3 \%$ on the DM, hence the digestibilities of nutrients were beneficial. Similar, results were reported by Ampapon and Wanapat [45].

\section{Rumen fermentation}

As described by Van Soest et al [46] rumen fermentation characteristics such as $\mathrm{pH}, \mathrm{NH} 3-\mathrm{N}$ concentration, protozoa should be measured to determine the relationship between the diet and rumen ecology. Under this study, ruminal $\mathrm{pH}$ was in the range of 6.8 to 7.0 which was a normal range for rumen ecology and the efficiency of rumen fermentation. $\mathrm{NH}_{3}-\mathrm{N}$ concentration was increased with the supplementation of CHYP. Similarly, Promkot and Wanapat [43] reported that $\mathrm{NH}_{3}-\mathrm{N}$ concentration increased with higher $\mathrm{CP}$ content

Table 4. Effects of supplementation of Cnidoscolus aconitifolius leaf pellet with various levels of protein of concentrate on volatile fatty acids and methane production

\begin{tabular}{|c|c|c|c|c|c|c|c|}
\hline \multirow{2}{*}{ Concentrates } & \multirow{2}{*}{$\mathrm{CHYP}^{1)}$} & \multicolumn{3}{|c|}{ VFA (mol/100 mL) } & \multirow{2}{*}{$\begin{array}{l}\text { Total VFA } \\
(\mathrm{mmol} / \mathrm{L})\end{array}$} & \multirow{2}{*}{$\mathrm{C}_{2}: \mathrm{C}_{3}{ }^{2)}$} & \multirow{2}{*}{$\mathrm{CH}_{4}{ }^{3)}(\mathrm{mmol} / \mathrm{L})$} \\
\hline & & $\mathrm{C}_{2}$ & $\mathrm{C}_{3}$ & $\mathrm{C}_{4}$ & & & \\
\hline \multirow[t]{5}{*}{$14 \%$ CP } & 0 & 64.2 & 27.1 & 13.2 & 73.7 & 2.4 & 26.1 \\
\hline & 2 & 62.7 & 26.3 & 12.3 & 75.0 & 2.3 & 26.3 \\
\hline & 4 & 63.8 & 26.6 & 12.5 & 73.8 & 2.4 & 26.6 \\
\hline & 6 & 65.1 & 28.5 & 10.4 & 75.2 & 2.2 & 25.5 \\
\hline & 8 & 63.6 & 27.6 & 12.4 & 75.8 & 2.3 & 26.1 \\
\hline \multirow[t]{5}{*}{$16 \%$ CP } & 0 & 64.2 & 26.6 & 12.7 & 75.4 & 2.4 & 26.4 \\
\hline & 2 & 63.2 & 26.9 & 12.6 & 76.5 & 2.3 & 26.7 \\
\hline & 4 & 63.7 & 26.6 & 12.8 & 77.9 & 2.4 & 26.5 \\
\hline & 6 & 63.9 & 34.7 & 10.1 & 75.1 & 1.8 & 23.6 \\
\hline & 8 & 62.6 & 34.5 & 8.9 & 76.5 & 1.7 & 23.3 \\
\hline \multirow[t]{5}{*}{$18 \% \mathrm{CP}$} & 0 & 64.2 & 30.5 & 13.1 & 76.6 & 2.0 & 25.3 \\
\hline & 2 & 62.3 & 31.0 & 12.1 & 79.3 & 2.1 & 23.8 \\
\hline & 4 & 65.9 & 27.7 & 11.4 & 80.9 & 2.4 & 26.6 \\
\hline & 6 & 63.7 & 32.6 & 10.3 & 80.8 & 1.9 & 23.9 \\
\hline & 8 & 63.6 & 30.4 & 11.0 & 81.1 & 2.1 & 24.0 \\
\hline SEM & & 0.71 & 0.95 & 0.39 & 1.02 & 0.06 & 0.16 \\
\hline $\mathrm{CP}$ & & ns & $\star \star$ & * & $\star \star$ & $\star \star$ & $\star \star$ \\
\hline CHYP & & $\star$ & $\star \star$ & $\star \star$ & * & $\star \star$ & $\star *$ \\
\hline Interaction & & ns & $\star$ & $\star$ & ns & $\star *$ & $\star \star$ \\
\hline
\end{tabular}

CHYP, Cnidoscolus aconitifolius leaf pellet; VFA, volatile fatty acids; CP, crude protein; SEM, standard error of mean.

1) CHYP, Chaya leaf pellet at $0 \%, 2 \%, 4 \%, 6 \%$, and $8 \%$ of total substrate.

2) $\mathrm{C}_{2}: \mathrm{C}_{3}$, acetic acid to propionate ratio;

${ }^{3)} \mathrm{CH}_{4}=\left(0.45 \times \mathrm{C}_{2}\right)-\left(0.275 \times \mathrm{C}_{3}\right)+\left(0.40 \times \mathrm{C}_{4}\right)$ (Moss et al [32]).

ns, not significant; ${ }^{*} p<0.05,{ }^{* *} p<0.001$ 
in dietary treatment. This could be due to the CHYP supplementation that enhanced rumen fermentation by providing more nutrients to the microorganisms to increase their feed degradation activities.

Furthermore, the protozoal counts were slightly decreased with increasing level of CHYP supplementation. This occurrence may be due to phytonutrients such as $\mathrm{CT}$ and flavonoids contained in the CHYP which reduced the protozoal population. Oskoueian et al [23] and Cushnie and Lamb [47] reported that phytonutrients may suppress the growth or activity of protozoa, through the inhibition of cytoplasmic membrane function and nucleic acid synthesis. Likewise, Rispoli et al [48] found the effect of phytonutrients significantly decreased protozoal populations in the rumen.

\section{Rumen volatile fatty acids concentration and methane production}

Higher VFA production increased with increased levels of CP concentrate and CHYP supplementation. Hume [49] stated that higher digestibility of feeds would contribute to enhanced concentrations of VFA in the rumen. Moreover, $\mathrm{C}_{2}$ was decreased in the treatment with CHYP supplementation, while $\mathrm{C}_{3}$ was greater when using $16 \% \mathrm{CP}$ of concentrate with $6 \%$ or $8 \%$ CHYP supplementation, while the $\mathrm{C}_{2}: \mathrm{C}_{3}$ ratio and $\mathrm{CH}_{4}$ were significantly decreased. Chen and Wolin [50] that $\mathrm{H}_{2}$ produced by the synthesis of $\mathrm{C}_{2}$ would be captured in the synthesis of $\mathrm{C}_{3}$ process, accordingly. As explained by Denman and McSweeney [51] methanogens are attached on the surface of protozoa in the rumen, when protozoa were decreased, hence, the methanogens would be suppressed accordingly. During rumen fermentation, $2 \%$ to $12 \%$ of ingested gross energy is changed to $\mathrm{CH}_{4}$, which lowers the efficiency of feed utilization [52]. Similarly, Seradj [53] reported that the supplementation of the phytonutrient Bioflavex decreased $\mathrm{CH}_{4}$ emission while $\mathrm{C}_{3}$ was increased. Additionally, Kamra [54] revealed that the phytonutrient used as feed additives would enhance the potential of rumen fermentation, reducing $\mathrm{CH}_{4}$ emission. Under this study, the supplementation of CHYP which contained phytonutrients decreased $\mathrm{CH}_{4}$ production in the rumen. Among natural plant secondary compounds, flavonoids, especially CTs and saponins, have been receiving more attention because of their wide range of biological activities and in particular, the antimicrobial properties and impacts on the rumen. Flavonoids are diverse group of phytonutrients found in almost all fruits and vegetables especially in Chaya leaf [55]. These natural compounds were shown to have direct effects against methanogens and to be an alternative agent to suppress $\mathrm{CH}_{4}$ production and hence, improve animal health and productivity [56].

\section{CONCLUSION}

Based on this study, it could be concluded that supplementation of $6 \%$ or $8 \%$ CHYP with $16 \% \mathrm{CP}$ of concentrate improved the IVDMD, enhanced the rumen $\mathrm{C}_{3}, \mathrm{C}_{2}: \mathrm{C}_{3}$ and mitigated the $\mathrm{CH}_{4}$ production. $\mathrm{CHYP}$ can be used as a supplemental feed to modulate the rumen fermentation and to increase feed utilization efficiency. Nevertheless, more in vivo work is suggested to help generate more data for further implementation.

\section{CONFLICT OF INTEREST}

We certify that there is no conflict of interest with any financial organization regarding the material discussed in the manuscript.

\section{ACKNOWLEDGMENTS}

The authors wish to make an invaluable thanks to Tropical Feed Resources Research and Development Center (TROFREC), Department of Animal Science, Faculty of Agriculture, Khon Kaen University, Khon Kaen, Thailand and Thailand Research Fund (TRF) through the Thailand Science Research and Innovation (TSRI) (TRF-IRN57W0002 and TRF-IRG5980010) for their kind support on research fund and facilities.

\section{REFERENCES}

1. Leng RA. Factors affecting the utilization of 'poor-quality' forages by ruminants particularly under tropical conditions. Nutr Res Rev 1990;3:277-303. https://doi.org/10.1079/NRR 19900016

2. Russell JB, Rychlik JL. Factors that alter rumen microbial ecology. Science 2001;292:1119-22. https://doi.org/10.1126/ science. 1058830

3. Papachristou TG, Papanastasis VP. Forage value of Mediterranean deciduous woody fodder species and its implication to management of silvo-pastoral systems for goats. Agroforest Syst 1994;27:269-82. https://doi.org/10.1007/BF00705061

4. Kemp DJ. The ecology of female receptivity in the territorial butterfly Hypolimnas bolina (L.) (Nymphalidae): implications for mate location by males. Aust J Zool 2001;49:203-11. https:// doi.org/10.1071/ZO01027

5. Pitta DW, Barry TN, Lopez-Villalobos N, Kemp PD. Effects on ewe reproduction of grazing willow fodder blocks during drought. Anim Feed Sci Technol 2005;120:217-34. https:// doi.org/10.1016/j.anifeedsci.2005.02.030

6. Abdulrazak SA, Muinga RW, Thorpe W, Ørskov ER. The effects of supplementation with Gliricidia sepium or Leucaena leucocephala forage on intake, digestion and live-weight gains 
of Bos taurus $\times$ Bos indicus steers offered napier grass. Anim Sci 1996;63:381-8. https://doi.org/10.1017/S1357729800 015265

7. Gardiner C, Parker A. Steer liveweight gains on Progardes desmanthus/buffel pastures in Queensland. In: Proceedings of Second Joint Conference of the New Zealand Society of Animal Production and the Australian Society of Animal Production; 2012 Jul 2-5; Lincoln University, Christchurch, New Zealand.

8. Maasdorp BV, Muchenje V, Titterton M. Palatability and effect on dairy cow milk yield of dried fodder from the forage trees Acacia boliviana, Calliandra calothyrsus and Leucaena leucocephala. Anim Feed Sci Technol 1999;77:49-59. https://doi. org/10.1016/S0377-8401(98)00232-6

9. Baumer P, Dorval ED, Bertrand J, Vetel JM, Schwartz JC, Lecomte JM. Effect of acetorphan, an enkephalinase inhibitor, on experimental and acute diarrhoea. Gut 1992;33:753-8.

10. Smith OB. Fodder trees and shrubs in range and farming systems in tropical humid Africa. In: Legume trees and other fodder trees as protein sources for livestock. Rome, Italy: FAO; 1992. FAO Animal Porduction and Health Paper 102.

11. Idan F, Adogla-Bessa T, Amaning-Kwarteng K. Preference, voluntary feed intake, and digestibility of sheep fed untreated rice straw and supplemented with sole or combined fodder tree leaves. Eur J Agric Food Sci 2020;2(4). https://doi.org/ 10.24018/ejfood.2020.2.4.89

12. Waghorn G. Beneficial and detrimental effects of dietary condensed tannins for sustainable sheep and goat production -Progress and challenges. Anim Feed Sci Technol 2008; 147:116-39. https://doi.org/10.1016/j.anifeedsci.2007.09.013

13. Hess HD, Beuret RA, Lötscher M, et al. Ruminal fermentation, methanogenesis and nitrogen utilization of sheep receiving tropical grass hay-concentrate diets offered with Sapindus saponaria fruits and Cratylia argentea foliage. Anim Sci 2004;79:177-89. https://doi.org/10.1017/S1357729800 054643

14. Viennasay B, Wanapat M. Strategic supplementation of Flemingia silage to enhance rumen fermentation efficiency, microbial protein synthesis and methane mitigation in beef cattle. BMC Vet Res 2020;16:480. https://doi.org/10.1186/ s12917-020-02703-x

15. Mupeyo B, Barry TN, Pomroy WE, Ramírez-Restrepo CA, López-Villalobos N, Pernthaner A. Effects of feeding willow (Salix spp.) upon death of established parasites and parasite fecundity. Anim Feed Sci Technol 2011;164:8-20. https:// doi.org/10.1016/j.anifeedsci.2010.11.015

16. Ramírez-Restrepo CA, Barry TN, Marriner A, et al. Effects of grazing willow fodder blocks upon methane production and blood composition in young sheep. Anim Feed Sci Technol 2010;155:33-43. https://doi.org/10.1016/j.anifeedsci. 2009.10.003

17. Speedy A, Pugliese PL. Legume trees and other fodder trees as protein sources for livestock (No. 633.3/S742). Proceedings of the FAO Expert Consultation held at the Malaysian Agricultural Research and Development Institute (MARDI). Rome, Italy: FAO; 1992.

18. Ansah T, Nagbila DA. Utilization of local trees and shrubs for sustainable livestock production in the Talensi-Nabdam district of the upper East region of Ghana. Livest Res Rural 2011;23:75.

19. Donkoh A, Atuahen CC, Poku-Prempeh YB, Twum IG. The nutritive value of chaya leaf meal (Cnidoscolus aconitifolius (Mill.) Johnston): studies with broiler chickens. Anim Feed Sci Technol 1999;77:163-72. https://doi.org/10.1016/S03778401(98)00231-4

20. Ebel R, de Jesús Méndez-Aguilar M, Interian-Sandoval CV. Optimum planting density for rainfed production of Chaya (Cnidoscolus aconitifolius). In: 2016 ASHS Annual Conference. ASHS; 2016.

21. Sarmiento-Franco L, Sandoval-Castro CA, McNab JM, Quijano-Cervera R, Reyes-Ramirez RR. Effect of age of regrowth on chemical composition of chaya (Cnidoscolus aconitifolius) leaves. J Sci Food Agric 2003;83:609-12. https:// doi.org/10.1002/jsfa.1372

22. Victor M, Abbey PA, Yohaya J, Zakka J, Yatai B, Oladeji M. An underexploited tropical plant with promising economic value and the window of opportunities for researches: Cnidoscolus aconitifolius. Am J Food Sci Nutr Res 2016;3:177-87.

23. Oskoueian E, Abdullah N, Oskoueian A. Effects of flavonoids on rumen fermentation activity, methane production, and microbial population. Biomed Res Int 2013;2013:Article ID 349129. https://doi.org /10.1155/2013/349129

24. AOAC. Official methods of analysis, 19th ed. Association of Official Analytical Chemists. Gaithersburg, MD, USA: AOAC International; 2012.

25. Burns RE. Method for estimation of tannin in grain sorghum. Agron J 1971;63:511-2. https://doi.org/10.2134/agronj1971. 00021962006300030050x

26. Wanapat M, Poungchompu O. Method for estimation of tannin by vanillin- $\mathrm{HCl}$ method. Khon Kaen, Thailand: Department of Animal Science, Khon Kaen University; 2001.

27. Hafizah AH, Zaiton Z, Zulkhairi A, Ilham AM, Anita MMNN, Zaleha AM. Piper sarmentosum as an antioxidant on oxidative stress in human umbilical vein endothelial cells induced by hydrogen peroxide. J Zhejiang Univ Sci 2010;11:357-65. https:// doi.org/10.1631/jzus.B0900397

28. Menke KH, Steingass H. Estimation of the energetic feed value obtained from chemical analysis and in vitro gas production using rumen fluid. Anim Res Dev 1988;28:9-55.

29. Blummel M, Orskov ER. Comparison of in vitro gas production and nylon bag degradability of roughages in predicting of food intake in cattle. Anim Feed Sci Technol 1993;40: 109-19. https://doi.org/10.1016/0377-8401(93)90150-I

30. Ørskov ER, McDonald I. The estimation of protein degrad- 
ability in the rumen from incubation measurements weighted according to rate of passage. J Agric Sci 1979;92:499-503. https://doi.org/10.1017/S0021859600063048

31. Van Soest PJ, Robertson JB. Analysis of forages and fibrous foods a laboratory manual for animal science. Ithaca, NY, USA: Cornell University; 1985.

32. Mathew S, Sagathewan S, Thomas J, Mathen G. An HPLC method for estimation of volatile fatty acids of ruminal fluid. Indian J Anim Sci 1997;67:805-7.

33. Galyean ML. Laboratory procedure in animal nutrition research. Las Cruces, NM, USA: Department of Animal and Life Science, New Mexico State University; 1989.

34. Moss AR, Jouany JP, Newbold J. Methane production by ruminants: its contribution to global warming. Ann Zootech 2000;49:231-53. https://doi.org/10.1051/animres:2000119

35. SAS. User's guide. Statistic, Version 9.4th Edition. Cary, NC, USA: SAS Institute Inc.; 2013.

36. Devendra C. Use of shrubs and tree fodders by ruminants. In: Shrubs and tree fodders for farm animals: proceedings of a workshop in Denpasar, Indonesia, 24-29 July 1989. Ottawa, ON, Canada: IDRC; 1990.

37. Wanapat M, Kang S, Polyorach S. Development of feeding systems and strategies of supplementation to enhance rumen fermentation and ruminant production in the tropics. J Anim Sci Biotechnol 2013;4:32. https://doi.org/10.1186/2049-18914-32

38. García-Rodríguez RV, Gutiérrez-Rebolledo GA, MéndezBolaina E, et al. Cnidoscolus chayamansa Mc Vaugh, an important antioxidant, anti-inflammatory and cardioprotective plant used in Mexico. J Ethnopharmacol 2014;151:937-43. https://doi.org/10.1016/j.jep.2013.12.004

39. Sarmiento-Franco L, McNab JM, Pearson A, Belmar-Casso $\mathrm{R}$. The effect of chaya (Cnidoscolus aconitifolius) leaf meal and of exogenous enzymes on amino acid digestibility in broilers. Br Poult Sci 2003;44:458-63. https://doi.org/10.108 0/00071660310001598256

40. Kuri-Garcia A, Chavez-Servin JL, Guzman-Maldonado SH. Phenolic profile and antioxidant capacity of Cnidoscolus chayamansa and Cnidoscolus aconitifolius: A review. J Med Plants Res 2017;11:713-27. https://doi.org/10.5897/JMPR 2017.6512

41. Norrapoke T, Wanapat M, Cherdthong A, Kang S, Phesatcha $\mathrm{K}$, Pongjongmit T. Improvement of nutritive value of cassava pulp and in vitro fermentation and microbial population by urea and molasses supplementation. J Appl Anim Res 2018; 46:242-7. https://doi.org/10.1080/09712119.2017.1288630

42. Anantasook N, Wanapat M. Influence of rain tree pod meal supplementation on rice straw based diets using in vitro gas fermentation technique. Asian-Australas J Anim Sci 2012; 25:325-34. https://doi.org/10.5713/ajas.2011.11131
43. Promkot C, Wanapat M. Effect of level of crude protein and use of cottonseed meal in diets containing cassava chips and rice straw for lactating dairy cows. Asian-Australas J Anim Sci 2005;18:502-11. https://doi.org/10.5713/ajas.2005.502

44. Woodward SL, Laboyrie PJ, Jansen EBL. Lotus corniculatus and condensed tannins-effects on milk production by dairy cows. Asian-Australas J Anim Sci 2000;13(Suppl):521-5.

45. Ampapon T, Wanapat M. Dietary rambutan peel powder as a rumen modifier in beef cattle. Asian-Australas J Anim Sci 2020;33:763-9. https://doi.org/10.5713/ajas.19.0342

46. Van Soest PJ, Robertson JB, Lewis BA. Methods for dietary fiber, neutral detergent fiber, and non starch polysaccharides in relation to animal nutrition. J Dairy Sci 1991;74:3583-97. https://doi.org/ 10.3168/jds.S0022-0302(91)78551-2

47. Tim Cushnie TP, Lamb AJ. Antimicrobial activity of flavonoids. Int J Antimicrob Agents 2005;26:343-56. https://doi.org/10. 1016/j.ijantimicag.2005.09.002

48. Rispoli TB, Rodrigues IL, Martins Neto RG, et al. Ruminal ciliate protozoa of cattle and buffalo fed on diet supplemented with monensin or extracts from propolis. Pesqui Agropecu Bras 2009;44:92-97. https://doi.org/10.1590/S0100-204X200 9000100013

49. Hume ID. Production of volatile fatty acids in two species of wallaby and in sheep. Comp Biochem Physiol A Physiol 1977; 56:299-304. https://doi.org/10.1016/0300-9629(77)90241-9

50. Chen M, Wolin MJ. Effect of monensin and lasalocid-sodium on the growth of methanogenic and rumen saccharolytic bacteria. Appl Environ Microbiol 1979;38:72-7.

51. Denman SE, McSweeney CS. Development of a real-time PCR assay for monitoring anaerobic fungal and cellulolytic bacterial populations within the rumen. FEMS Microbiol Ecol 2006;58:572-82. https://doi.org/10.1111/j.1574-6941. 2006.00190.x

52. Johnson KA, Johnson DE. Methane emissions from cattle. J Anim Sci 1995;73:2483-92. https://doi.org/10.2527/1995. $7382483 \mathrm{x}$

53. Seradj AR. Study the effect of inclusion of feed flavonoid substances on animal performance and ruminal fermentation in calves [doctoral dissertation]. Lleida, Spain: Universitat de Lleida; 2014.

54. Kamra DN. Rumen microbial ecosystem. Curr Sci 2005;89: 124-35.

55. Crozier A, Del Rio D, Clifford MN. Bioavailability of dietary flavonoids and phenolic compounds. Mol Aspects Med 2010; 31:446-67. https://doi.org/10.1016/j.mam.2010.09.007

56. Bodas R, Prieto N, García-González R, Andrés S, Giráldez FJ, López S. Manipulation of rumen fermentation and methane production with plant secondary metabolites. Anim Feed Sci Technol 2012;176:78-93. https://doi.org/10.1016/j.ani feedsci.2012.07.010 